\title{
Identification of Vimentin Binding to the Derivative of Saurolactam with Antiresorptive Activity by Using Its Chemical Affinity Probe
}

\author{
Myung Hee Kim, ${ }^{\dagger, \S}$ Young Lok Choi, ${ }^{\ddagger}$ Jung-Nyoung Heo, ${ }^{\ddagger}$ Yong Ki Min, ${ }^{\dagger}$ and Seong Hwan Kim ${ }^{\dagger}, *$ \\ ${ }^{\dagger}$ Laboratory of Chemical Genomics, Pharmacology Research Center, Korea Research Institute of Chemical Technology, \\ Daejeon 305-600, Korea. ${ }^{*}$-mail: hwan@krict.re.kr \\ ${ }^{\star}$ Medicinal Chemistry Research Center, Korea Research Institute of Chemical Technology, Daejeon 305-600, Korea \\ ${ }^{\S}$ Department of Biochemistry, Chungnam National University Graduate School, Daejeon 305-764, Korea \\ Received February 18, 2010, Accepted May 3, 2010
}

Key Words: Chemical proteomics, Chemical affinity matrix, Osteoclastogenesis, Saurolactam, Vimentin

In the application of proteomics, the entire complement of expressed proteins (the proteome) can be presented in terms of their regulation by multiple factors including cytokines, metabolites, and chemicals or as they are expressed in distinct cellular processes, whereas chemical proteomics involves the identification and validation of the target protein(s) of a particular bioactive small molecule. Thus, correlation of a property or mechanism of the chemical with a specific biological process and, further, the discovery of new target proteins that bind to a class of chemicals or drugs with good efficacy could be starting points for the development of new therapeutics for diseases by using the screening systems based on the structure of the newly identified target protein. ${ }^{1}$

The process to identify and validate the protein targets of bioactive small molecules discovered through cell-based assays is an important step in preclinical drug development. Several strategies have been developed to detect target protein(s) that can directly interact with the bioactive small molecule. For the specific capture of target proteins and the rapid mapping of peptides containing binding-epitopes, ligand-encapsulated nanoprobes and photoaffinity probes have been used in several studies; some of these probes are able to distinguish the inter- actions between the small molecule and its target protein even though the binding interactions are weak and readily reversible. ${ }^{2}$ Additionally, to clarify the nonspecific interactions between the proteins and the small molecule ligands, positive/negative chemical affinity matrices-based chemical proteomics has been applied. ${ }^{3}$ Although these applications have some limitations, their contribution toward identification of target protein(s) could advance our understanding of the mechanism of biological action of bioactive small molecule at the cellular level.

To maintain skeletal strength and integrity, bone is constantly remodeled by the balance between osteoblast-mediated bone formation and osteoclast-mediated bone resorption. However, an imbalance in bone remodeling favoring increased bone resorption over bone formation leads to the reduction of bone mineral density, a major cause of several bone disorders such as osteoporosis. ${ }^{4}$ Therefore, antiresorptive agents are the therapeutic mainstay for bone resorption-related disorders.

In a previous study, we found that the natural compound, saurolactam (7) (Figure 1A) has the potential to inhibit the osteoclast differentiation. ${ }^{5}$ Since mouse RAW264.7 monocyte/ macrophage cells retain the capacity to differentiate into osteoclast-like cells in the presence of the receptor activator of nuclear
(A)<smiles></smiles>

7

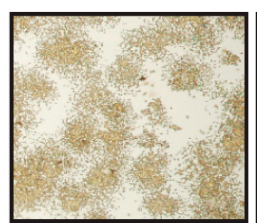

(C)

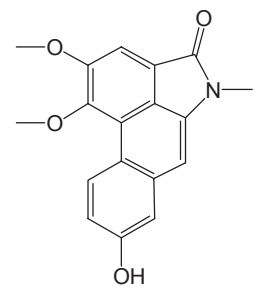

$7 a$
(B)

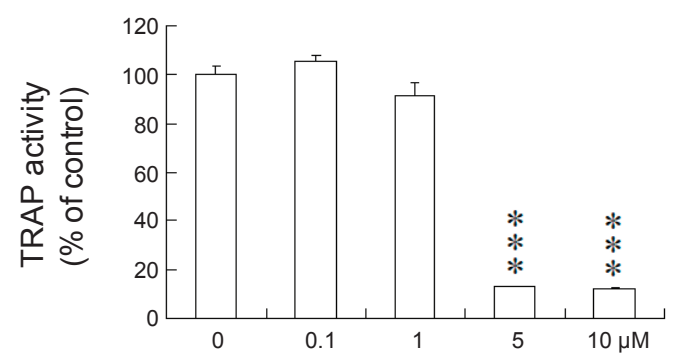

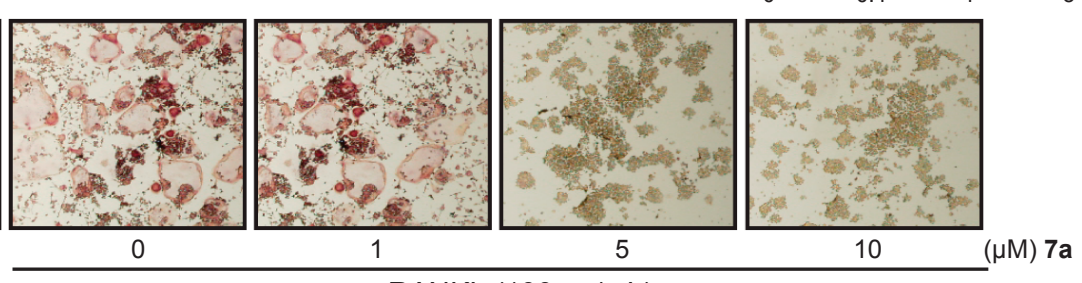

+ RANKL $(100 \mathrm{ng} / \mathrm{mL})$

Figure 1. (A) Structures of saurolactam (7) and its derivative (7a) with antiresorptive activity. (B) Effect of 7a on the RANKL-induced TRAP activity in RAW264.7 cells was evaluated as described in reference 7. ***, $<0.001(\mathrm{C})$ Effect of $7 \mathbf{a}$ on the formation of MNCs was evaluated by TRAP staining method. 

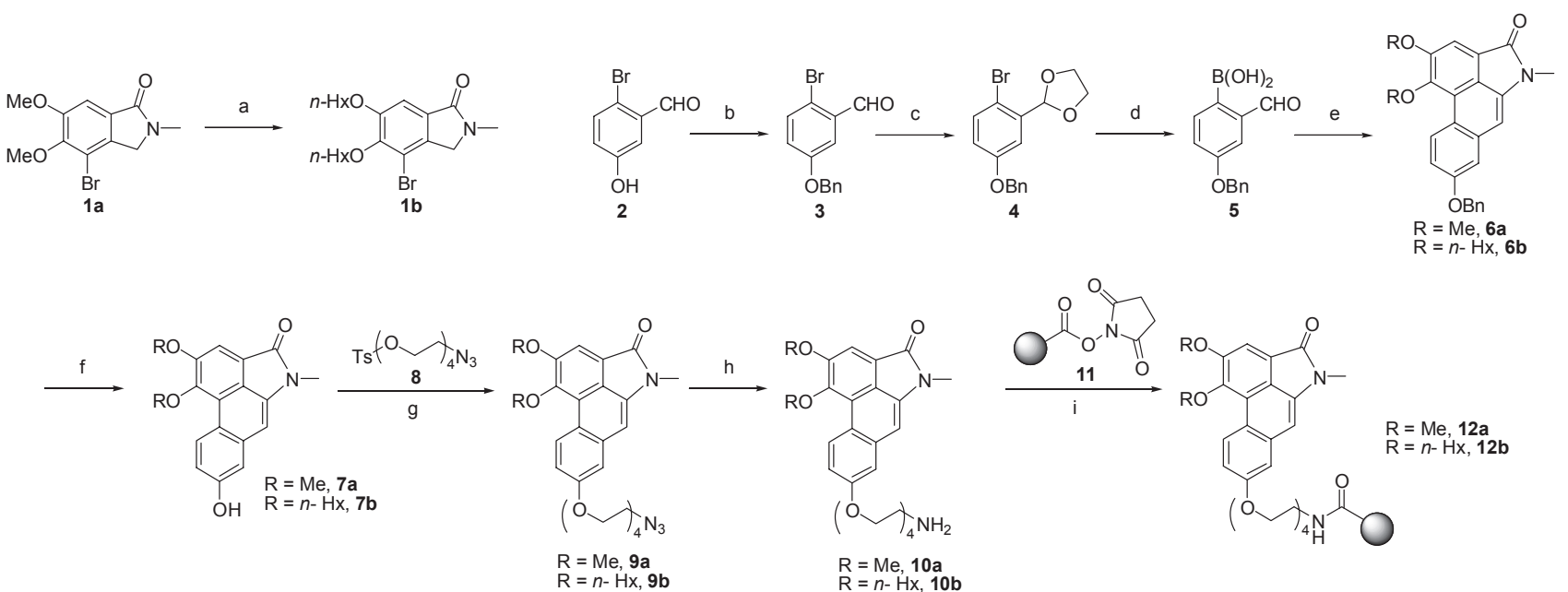

Reaction conditions: (a) i) $\mathrm{BBr}_{3}$ (15 eq), $\mathrm{CH}_{2} \mathrm{Cl}_{2}$, rt, overnight, ii) bromohexane (3.0 eq), $\mathrm{K}_{2} \mathrm{CO}_{3}\left(10\right.$ eq), DMF, rt, overnight, $60 \%$. (b) $\mathrm{BnBr}$ (1.3 eq), $\mathrm{K}_{2} \mathrm{CO} 3$ (1.5 eq), DMF, rt, $2 \mathrm{~h}, 99 \%$. (c) ethyleneglycol (5.0 eq), PTSA (0.03 eq), $\mathrm{C}_{6} \mathrm{H}_{6}$, reflux, $12 \mathrm{~h}, 99 \%$. (d) i) $n$-BuLi (1.2 eq), THF, $-78^{\circ} \mathrm{C}, 1 \mathrm{~h}$; ii) B(O'Pr) 3 (1.3 eq), $-78{ }^{\circ} \mathrm{C} \rightarrow \mathrm{rt}, 12 \mathrm{~h}$; iii) $4 \mathrm{M} \mathrm{HCl}, 65 \%$. (e) $1 \mathrm{a}$ or $1 \mathrm{~b}, \mathrm{Pd}\left(\mathrm{PPh}_{3}\right)_{4}(4 \mathrm{~mol} \%), \mathrm{Cs}_{2} \mathrm{CO}_{3}(3.0 \mathrm{eq})$, toluene/EtOH $(2: 1)$, microwave $150{ }^{\circ} \mathrm{C}, 15 \mathrm{~min}, 6 \mathrm{a}: 56 \%, 6 \mathbf{b}$ : $86 \%$. (f) Pd/C (20 wt \%), $\mathrm{H}_{2}$ (1 atm), MeOH, rt, 5 h, 7a: $73 \%, 7 b: 98 \%$. (g) 8 (1.5 eq), $\mathrm{K}_{2} \mathrm{CO}_{3}(5.0$ eq), DMF, reflux, 6 h, 9a: $82 \%, 9 b: 59 \%$. (h) PtO 2 (20 wt $\%), \mathrm{H}_{2}(1 \mathrm{~atm}), \mathrm{MeOH}, \mathrm{rt}, 10 \mathrm{~h}$. (i) $11, \mathrm{Et}_{3} \mathrm{~N}, \mathrm{DMSO}$, rt, overnight.

Scheme 1. Synthesis of chemical affinity matrices $\mathbf{1 2 a}$ and $\mathbf{1 2 b}$

factor- $\kappa \mathrm{B}$ ligand (RANKL) which is essential and sufficient to promote the maturation of osteoclasts, ${ }^{6}$ we used RAW264.7 cells as the in vitro model for osteoclast differentiation. Cell culture, differentiation induction, TRAP staining, and TRAP activity assay were performed as described previously. ${ }^{7}$ The previous structure-activity relationship study also revealed that 7a(Figure 1A), a derivative of 7 in which the hydroxyl moiety at $C_{2}$ position of 7 was converted to methoxy moiety and the hydroxyl moiety was added at $\mathrm{C}_{8}$ position of 7 , also exhibited an inhibitory effect on the osteoclast differentiation without cytotoxicity in RAW264.7 cells; compound 7a significantly inhibited the RANKL-induced activity of tartrate-resistant acid phosphatase (TRAP; a marker for osteoclast differentiation) (Figure 1B). There were no multinucleated osteoclasts (MNCs) in the absence of RANKL as shown in the left image of Figure 1C. When RANKL was added, cells were differentiated into MNCs, but the addition of $7 \mathrm{a}$ inhibited the RANKL-induced formation of MNCs (Figure 1C). However, a derivative $\mathbf{7 b}$ in which the methyl moieties at $C_{1}$ and $C_{2}$ positions of $7 \mathbf{a}$ were converted to hexyl groups (Scheme 1), was not inhibitory (data not shown).

Compounds $7 \mathbf{a}$ and $\mathbf{7 b}$ can be synthesized by following our previously reported methods (Scheme 1). ${ }^{8}$ Starting from commercially available 2-bromo-5-hydroxybenzaldehyde (2), 2-formylphenylboronic acid $\mathbf{5}$ was prepared through a straightforward 3-step sequence. ${ }^{9}$ The direct one-pot synthesis of phenanthrene lactams 6a-b was successfully demonstrated by reaction of $\mathbf{5}$ with isoindolone $\mathbf{1} \mathbf{a}-\mathbf{b}^{8 \mathrm{a}}$ via Suzuki-Miyaura coupling/ aldol condensation cascade under microwave irradiation. Debenzylation of $\mathbf{6} \mathbf{a}-\mathbf{b}$ by catalytic hydrogenation provided the corresponding compounds $\mathbf{7 a - b}$ in excellent yields. ${ }^{10}$

With compounds $\mathbf{7 a - b}$ in hand, we introduced the hydrophilic spacer polyethylene glycol (PEG) through a phenyl ether linkage. Phenolic alkylation of $\mathbf{7 a - b}$ with azido-tosylate $\mathbf{8}$ provided phenyl ethers 9a-b in $82 \%$ and 59\% yield, respectively. ${ }^{11}$ Catalytic reduction of azides $\mathbf{9 a - b}$ afforded amine compounds 10a-b. Finally, compounds 10a-b were linked with Affigel-10 (11), a widely used affinity resin, via formation of an amide bond, thus providing the respective positive and negative affinity matrices $\mathbf{1 2 a}$ and $\mathbf{1 2 b}$.

In parallel with the synthesis of the affinity matrices of $7 \mathbf{a}$ with antiresorptive activity, we evaluated the intermediate compounds acquired in the syntheses of $\mathbf{1 2 a}$ and $\mathbf{1 2 b}$ for their biological activities. When we introduced PEG into the $N$-methyl position of $7 \mathbf{a}$ or $\mathbf{7 b}$, the new compounds did not exhibit an inhibitory effect on TRAP activity, but the cytotoxicity increased (data not shown). However, 9a, characterized by a PEG spacer introduced into the hydroxyl moiety of 7a, exhibited an inhibitory effect on both TRAP activity and on formation of MNCs, as was observed with the parent compound, 7a (Figure 2). Additionally, 9b, with a PEG spacer inserted into the hydroxyl moiety of $\mathbf{7 b}$, did not exhibit an inhibitory effect on TRAP activity or on formation of MNCs, negative observations consistent with those for $\mathbf{7 b}$. Thus, we felt confident to proceed with the preparation of the positive (12a) or the negative affinity matrix (12b) bearing the respective spacer-introduced $9 \mathbf{a}$ or 9b onto AffiGel-10 (11).

In order to identify the protein(s) that bind on 12a, the affinity resins were incubated with RAW264.7 cell lysate and then the bound proteins on each affinity resin were resolved by SDSPAGE as shown in Figure 3A. The arrow-indicated protein that was shown to be bound on 12a, but not $\mathbf{1 2 b}$, was identified as vimentin (MASCOT score, 114) by LCQ mass spectrometry peptide mass fingerprinting after in-gel digestion.

To confirm whether vimentin could specifically interact with 12a, western blot analysis was performed as described previously. ${ }^{7}$ Vimentin was strongly detected in protein samples eluted from the positive probe 12a, but not from the negative probe $\mathbf{1 2 b}$ (Figure 3B).

Vimentin, one of the type III intermediate filament (IF) proteins, is expressed during development in a wide range of cells, including mesenchymal cells and in a variety of cultured cell 
lines and tumors. ${ }^{12}$ IFs are essential for structural and mechanical integration of the cellular space and a variety of cellular processes such as mitosis, motility, differentiation, and organizational cell architecture. However, the functional role of vimentin in the process of osteoclast differentiation has not been examined before. We examined the mRNA expression level of vimentin and found that vimentin mRNA expression was significantly increased by RANKL, suggesting that vimentin might play a role in the RANKL-induced osteoclast differentiation (data not shown). To confirm whether vimentin is involved in the RANKL-induced osteoclast differentiation, the effect of vimentin siRNA on RANKL-induced formation of TRAP-positive MNCs was evaluated. The expression of vimentin protein was decreased by exposure to its specific siRNA (Figure 3C) and, furthermore, vimentin siRNA significantly decreased the number of TRAP-positive MNCs in a dose-depen-
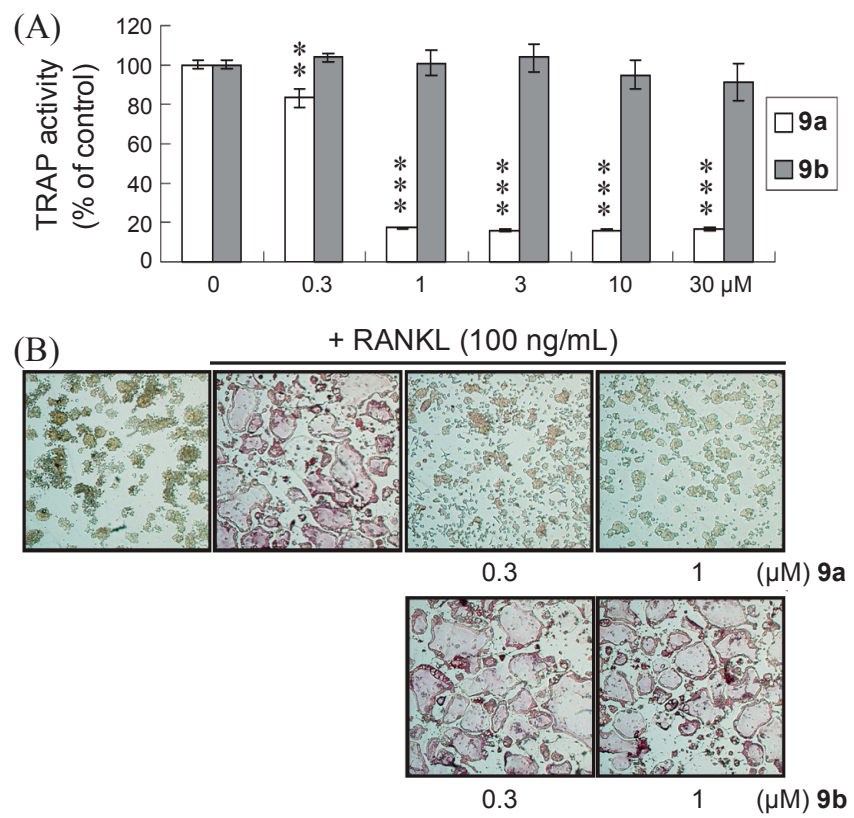

Figure 2. (A) Effects of 9a and 9b on the RANKL-induced TRAP activity in RAW264.7 cells were evaluated as described in reference 7. **, $p<0.01 ; * * *, p<0.001$ (B) Effects of $9 \mathbf{a}$ and $\mathbf{9 b}$ on the formation of MNCs were evaluated by TRAP staining method. dent manner (Figures 3D and 3E). These results indicated that vimentin could be one of the target proteins for $7 \mathbf{a}$ with antiresorptive activity.

In summary, we found that saurolactam (7) and its derivative (7a) have the potential to inhibit the formation of osteoclasts. We identified vimentin as at least one of the target proteins for 7a with antiresorptive activity by using a chemical affinity matrix-based chemical proteomics approach. Although additional biochemical characterization will be required to validate target protein(s) for bioactive small molecules, the initial identification of target proteins by using chemical proteomics can provide important insights into the mechanism of action of bioactive small molecules. Our Affigel-linked probe represents an important chemical proteomics tool that can advance our understanding of the biological function of newly identified target proteins.

\section{Experimental Section}

Preparation of chemical affinity matrices. We immobilized 10a and 10b on Affigel-10 gel beads as the following. To a solution of $9 \mathbf{a}(20 \mathrm{mg})$ or $9 \mathbf{b}(15 \mathrm{mg})$ in methanol was added $\mathrm{PtO}_{2}(5 \mathrm{mg})$ and the suspension was stirred under hydrogen balloon (1 atm) for $5 \mathrm{~h}$ at room temperature. The reaction mixture was filtered through a Celite pad and the filtrate was concentrated in vacuo to afford $\mathbf{1 0 a}$ or $\mathbf{1 0 b}$, which were used without further purification. Affigel-10 ( $2 \mathrm{~mL}$ of $30 \mu \mathrm{mole})$ of was transferred into a $3 \mathrm{~mL}$ cartridge. The supernatant solvent was drained and affigel was washed with DMSO. Washed gel was transferred to glass vial. A solution of 10a $(3.2 \mathrm{mg}, 6.6 \mu \mathrm{mole})$ or $\mathbf{1 0 b}(4.1 \mathrm{mg}, 6.6 \mu \mathrm{mole})$ in $2 \mathrm{~mL} \mathrm{DMSO}$ and $200 \mu \mathrm{L} \mathrm{Et}_{3} \mathrm{~N}$ were added to the gel and the mixture was shaken well overnight at room temperature. Ethanolamine $(20 \mu \mathrm{L})$ was added to the reaction mixture and shake well for 3 hours. The slurry was transferred to the cartridge and the gel was washed with DMSO, water, and PBS. Immobilized product (12a or $\mathbf{1 2 b})$ is stored in PBS at $4{ }^{\circ} \mathrm{C}$.

Protein fractionation with chemical affinity matrices. In order to identify the protein(s) that bind on 12a, $100 \mu \mathrm{L}$ of the affinity resins (12a or 12b) were incubated with $1 \mathrm{mg}$ of lysate prepared from RAW264.7 cells at $4{ }^{\circ} \mathrm{C}$ for $16 \mathrm{~h}$; cells were lysed in ice-cold buffer consisting of $1 \mathrm{mM}$ EDTA, $1 \mathrm{mM}$ DTT, $1 \%$
(A)

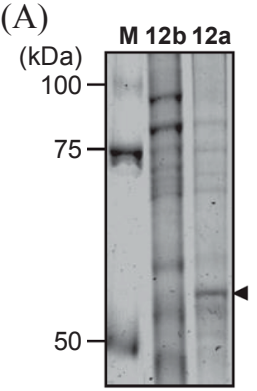

(B)

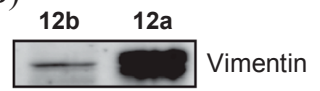

(C)

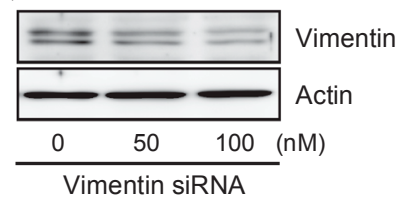

(D)

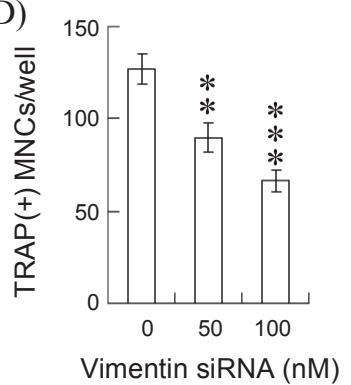

(E)

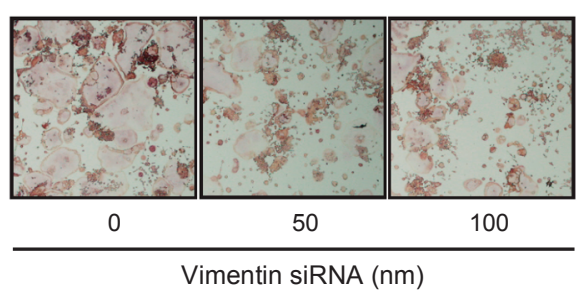

Figure 3. (A) Identification of putative 12a-binding proteins in RAW264.7 cell lysates. Putative positive chemical affinity matrix(12a)-binding proteins was identified in Coomassie Blue-stained $8 \%$ gel compared to the negative chemical affinity matrix(12b)-binding proteins. The left lane (M) was the standards of molecular weight. (B) Vimentin expression levels in bound fractions of 12a and $\mathbf{1 2} \mathbf{b}$ were evaluated with vimentin specific antibody. (C) Knock-down of vimentin protein expression by vimentin specific siRNA was evaluated with vimentin specific antibody. Actin was used as the control protein. (D) Effect of vimentin siRNA on the RANKL-induced formation of MNCs was evaluated by measuring the number of TRAP-positive MNCs/well. **, $p<0.01$; ***, $p<0.001$ (E) Effect of vimentin siRNA on the formation of MNCs was evaluated by TRAP staining method. 
NP-40, protease inhibitor cocktail and phosphatase inhibitor cocktail and centrifuged at $10,000 \times \mathrm{g}$ for $20 \mathrm{~min}$ at $4{ }^{\circ} \mathrm{C}$. Each affinity resin was then isolated by the centrifugation at $10,000 \times$ $\mathrm{g}$ for $30 \mathrm{sec}$ and washed three times with the wash buffer $(50$ mM Tris, 5 mM NaF, $250 \mathrm{mM} \mathrm{NaCl}, 5$ mM EDTA, 5 mM EGTA, $0.1 \%$ NP-40, protease inhibitor cocktail and phosphatase inhibitor cocktail). Then, the bound proteins on each affinity resin were eluted by $20 \mu \mathrm{L}$ of SDS-PAGE sample buffer $(100 \mathrm{mM}$ Tris- $\mathrm{HCl}, 2 \%$ sodium dodecyl sulfate, $1 \%$ 2-mercaptoethanol, $2 \%$ glycerol, $0.01 \%$ bromopenol blue, $\mathrm{pH} 7.6$ ).

SDS-PAGE and In-gel digestion. The eluted protein sample was separated on a $8 \%$ SDS-PAGE precasted gel (Invitrogen) and subsequently stained by colloidal Coomassie Brilliant Blue G-250 (CBB). Each of the gel was cut into several pieces, destained with $100 \mu \mathrm{L}$ of $10 \mathrm{mM}$ ammonium hydrogen carbonate $\left(\mathrm{NH}_{4} \mathrm{HCO}_{3}\right)$ for $10 \mathrm{~min}$, and further $10 \mathrm{~min}$ with $100 \mu \mathrm{L}$ of $5 \mathrm{mM}$ $\mathrm{NH}_{4} \mathrm{HCO}_{3}, 50 \%$ acetonitrile (v/v). The gel slices were dried in a Speedvac concentrator. The destained gel pieces were incubated overnight at $37{ }^{\circ} \mathrm{C}$ with trypsin $(0.02 \mu \mathrm{g} / \mu \mathrm{L}, \mathrm{w} / \mathrm{v})$ dissolved in $10 \mathrm{mM} \mathrm{NH}_{4} \mathrm{HCO}_{3}$ buffer ( $\mathrm{pH} 7.8$ ) and followed by extraction twice with $10 \mu \mathrm{L}$ of acetonitrile, $5 \%$ formic acid (50:50, v/v).

LCQ mass spectrometric data analysis. The extracted peptides were combined, dried in vacuo, and acidified by addition of $5 \%$ formic acid to a final volume of $2 \mu \mathrm{L}$. The acidified peptides were desalted using a microcolumn made of a GelLoader tip (Eppendorf), which was packed with $0.1 \mu \mathrm{L}$ of POROS R2 resin (Perseptive Biosystems, Framingham, MA). The desalted peptides were analyzed on an HP 1100 HPLC nano-flow system using a splitter (Agilent) coupled on-line to an LCQ DECA ion trap (Thermo Fisher Scientific, San Jose, CA). Zorbax 300SBC18 resin (particle size $5 \mu \mathrm{m}$, Agilent, CA) was packed into a home-built fused silica column $(100 \mathrm{~mm}$ length $\times 75 \mu \mathrm{m}$ I.D., tip diameter $10 \mu \mathrm{m})$. Peak lists from MS/MS spectra were exported as individual files in dta format using Bioworks 3.3 software (Thermo Fisher Scientific) and a single text file, which was generated by the automatic combination of the resulting dta files from each analysis, was searched against the National Center for Biotechnology Information (NCBI) non-redundant database using Mascot operating on a local server (version 2.1, Matrix Science).

siRNA experiment. To find out the involvement of vimentin on the process of osteoclastogenesis, the effect of vimentin specific siRNA (Sigma) on osteoclastogenesis was evaluated. RAW264.7 cells were seeded in a 6 -well plate at a density $5 \times$ $10^{5}$ cells/well. The next day, cells were transfected with 50 , $100 \mathrm{nM}$ of vimentin or mock siRNA using of Lipofectamine 2000 (Invitrogen) in $\alpha$-MEM. At $4 \mathrm{~h}$ after transfection, cells were replaced into a 96-well plate $\left(1 \times 10^{3}\right.$ cells/well $)$ or a 6 -well plate $\left(1 \times 10^{5}\right.$ cells/well $)$ for TRAP staining or western blot analysis, respectively. TRAP staining was performed in triplicate and TRAP-positive MNCs with 5 or more nuclei were counted. Significance was determined with the Student's t-test, and differences were considered significant at $P<0.05$. Western blot analysis and TRAP staining were performed as described in reference 7 .

Acknowledgments. This work was supported by a grant from the Korea Healthcare Technology R\&D Project, Ministry of Health, Welfare \& Family Affairs, Republic of Korea (A084242).

\section{References}

1. Han, S. Y.; Kim, S. H. Arch. Pharm. (Weinheim) 2007, 340, 169.

2. (a) Chen, Y. J.; Chen, S. H.; Chien, Y. Y.; Chang, Y. W.; Liao, H. K.; Chang, C. Y.; Jan, M. D.; Wang, K. T.; Lin, C. C. Chembiochem 2005, 6, 1169. (b) Tomohiro, T.; Hashimoto, M.; Hatanaka, Y. Chem. Rec. 2006, 5, 385. (c) Kim, M. H.; Han, S. Y.; Kim, B. T.; Min, Y. K.; Kim, S. H. Bull. Korean Chem. Soc. 2006, 27, 1285.

3. (a) Harding, M. W.; Galat, A.; Uehling, D. E.; Schreiber, S. L. Nature 1989, 341, 758. (b) Oda, Y.; Owa, T.; Sato, T.; Boucher, B.; Daniels, S.; Yamanaka, H.; Shinohara, Y.; Yokoi, A.; Kuromitsu, J.; Nagasu, T. Anal. Chem. 2003, 75, 2159.

4. Boyle, W. J.; Simonet, W. S.; Lacey, D. L. Nature 2003, $423,337$.

5. Kim, M. H.; Ryu, S. Y.; Choi, J. S.; Min, Y. K.; Kim, S. H. J. Cell. Physiol. (in press)

6. Hsu, H.; Lacey, D. L.; Dunstan, C. R.; Solovyev, I.; Colombero, A.; Timms, E.; Tan, H. L.; Elliott, G.; Kelley, M. J.; Sarosi, I.; Wang, L.; Xia, X. Z.; Elliott, R.; Chiu, L.; Black, T.; Scully, S.; Capparelli, C.; Morony, S.; Shimamoto, G.; Bass, M. B.; Boyle, W. J. Proc. Natl. Acad. Sci. USA 1999, 96, 3540.

7. Kim, M. H.; Ryu, S. Y.; Bae, M. A.; Choi, J. S.; Min, Y. K.; Kim, S. H. Food Chem. Toxicol. 2008, 46, 3375.

8. (a) Kim, J. K.; Kim, Y. H.; Nam, H, T.; Kim, B. T.; Heo, J.-N. Org. Lett. 2008, 10, 3543. (b) Choi, Y. L.; Kim, J. K.; Choi, S.-U.; Min, Y.-K.; Bae, M.-A.; Kim, B. T.; Heo, J.-N. Bioorg. Med. Chem. Lett. 2009, 19, 3036. (c) Kim, Y. H.; Lee, H.; Kim, Y. J.; Kim, B. T.; Heo, J.-N. J. Org. Chem. 2008, 73, 495.

9. Geen, G. R.; Mann, I. S.; Mullane, M. V.; McKillop, A. Tetrahedron $1998,54,9875$.

10. Data for 7a: ${ }^{1} \mathrm{H}$ NMR $\left(300 \mathrm{MHz}, \mathrm{CDCl}_{3}\right) \delta 9.10(\mathrm{~d}, 1 \mathrm{H}, J=9.0$ $\mathrm{Hz}), 7.73(\mathrm{~s}, 1 \mathrm{H}), 7.24(\mathrm{~d}, 1 \mathrm{H}, J=2.6 \mathrm{~Hz}), 7.09(\mathrm{dd}, 1 \mathrm{H}, J=9.0$, $2.6 \mathrm{~Hz}), 6.88(\mathrm{~s}, 1 \mathrm{H}), 5.23$ (brs, 1H), $4.09(\mathrm{~s}, 3 \mathrm{H}), 4.05(\mathrm{~s}, 3 \mathrm{H})$, $3.48(\mathrm{~s}, 3 \mathrm{H}) ;{ }^{13} \mathrm{C}$ NMR $(125 \mathrm{MHz}$, DMSO-d $) \delta 166.9,157.0$, 154.2, 149.3, 136.9, 136.7, 128.4, 121.1, 120.7, 120.1, 118.7, 115.3, 113.3, 108.5, 103.8, 59.8, 56.9, 26.2; MS (EI) $\mathrm{m} / \mathrm{z} 309\left(\mathrm{M}^{+}\right.$, 100), 294 (17), 266 (21), 251 (10), 238 (10), 220 (5), 195 (18), 139 (25). Data for $7 \mathbf{b}:{ }^{1} \mathrm{H} \mathrm{NMR}\left(300 \mathrm{MHz}, \mathrm{CDCl}_{3}\right) \delta 9.19(\mathrm{~d}, 1 \mathrm{H}$, $J=9.0 \mathrm{~Hz}), 7.71(\mathrm{~s}, 1 \mathrm{H}), 7.23(\mathrm{~d}, 1 \mathrm{H}, J=2.5 \mathrm{~Hz}), 7.06(\mathrm{dd}, 1 \mathrm{H}$, $J=9.0,2.7 \mathrm{~Hz}), 6.87(\mathrm{~s}, 1 \mathrm{H}), 5.11$ (brs, $1 \mathrm{H}), 4.23(\mathrm{t}, 2 \mathrm{H}, J=6.8$ $\mathrm{Hz}), 4.16(\mathrm{t}, 2 \mathrm{H}, J=6.8 \mathrm{~Hz}), 3.47(\mathrm{~s}, 3 \mathrm{H}), 2.02-1.87(\mathrm{~m}, 4 \mathrm{H})$, $1.60-1.52(\mathrm{~m}, 4 \mathrm{H}), 1.41-1.36(\mathrm{~m}, 8 \mathrm{H}), 0.95-0.91(\mathrm{~m}, 6 \mathrm{H}) ;{ }^{13} \mathrm{C}$ NMR $\left(125 \mathrm{MHz}\right.$, DMSO- $\left.d_{6}\right) \delta 166.9,153.4,148.6,137.0,136.6$, $128.3,121.1,120.5,120.4,115.0,113.3,109.2,103.7,72.4$, $69.3,31.1,29.8,29.0,26.1,25.4,25.2,22.1,13.9$; MS (EI) $\mathrm{m} / \mathrm{z}$ $449\left(\mathrm{M}^{+}, 61\right), 365$ (43), $281(100), 252$ (18).

11. Data for 9a: ${ }^{1} \mathrm{H}$ NMR $\left(300 \mathrm{MHz}, \mathrm{CDCl}_{3}\right) \delta 9.10(\mathrm{~d}, 1 \mathrm{H}, J=9.1$ $\mathrm{Hz}), 7.73(\mathrm{~s}, 1 \mathrm{H}), 7.28(\mathrm{~d}, 1 \mathrm{H}, J=2.7 \mathrm{~Hz}), 7.18(\mathrm{dd}, 1 \mathrm{H}, J=9.1$, $2.7 \mathrm{~Hz}), 6.91(\mathrm{~s}, 1 \mathrm{H}), 4.30(\mathrm{t}, 2 \mathrm{H}, J=4.8 \mathrm{~Hz}), 4.09(\mathrm{~s}, 3 \mathrm{H}), 4.06$ $(\mathrm{s}, 3 \mathrm{H}), 3.95(\mathrm{t}, 2 \mathrm{H}, J=4.8 \mathrm{~Hz}), 3.80-3.65(\mathrm{~m}, 10 \mathrm{H}), 3.48(\mathrm{~s}, 3 \mathrm{H})$, $3.38(\mathrm{t}, 2 \mathrm{H}, J=5.2 \mathrm{~Hz}) ;{ }^{13} \mathrm{C}$ NMR $\left(125 \mathrm{MHz}\right.$, DMSO- $\left.d_{6}\right) \delta 166.8$, $157.6,154.2,149.5,137.2,136.5,128.3,121.3,120.7,119.9$, $119.8,114.7,111.8,109.1,103.9,70.0,69.9,69.8,69.7,69.2$, $68.9,67.2,59.9,56.9,50.0,26.1$; MS (EI) $m / z 510\left(\mathrm{M}^{+}, 100\right)$, 397 (10), 309 (67), 294 (15), 281 (31), 266 (18). Data for 9 b: ${ }^{1} \mathrm{H}$ $\operatorname{NMR}\left(300 \mathrm{MHz}, \mathrm{CDCl}_{3}\right) \delta 9.19(\mathrm{~d}, 1 \mathrm{H}, J=9.1 \mathrm{~Hz}), 7.70(\mathrm{~s}, 1 \mathrm{H})$, $7.27(\mathrm{~d}, 1 \mathrm{H}, J=2.7 \mathrm{~Hz}), 7.16(\mathrm{dd}, 1 \mathrm{H}, J=9.1,2.7 \mathrm{~Hz}), 6.90(\mathrm{~s}$, $1 \mathrm{H}), 4.29(\mathrm{t}, 2 \mathrm{H}, J=4.8 \mathrm{~Hz}), 4.23(\mathrm{t}, 2 \mathrm{H}, J=6.8 \mathrm{~Hz}), 4.16(\mathrm{t}, 2 \mathrm{H}$, $J=6.8 \mathrm{~Hz}), 3.95(\mathrm{t}, 2 \mathrm{H}, J=4.8 \mathrm{~Hz}), 3.80-3.65(\mathrm{~m}, 10 \mathrm{H}), 3.47(\mathrm{~s}$, $3 \mathrm{H}), 3.37(\mathrm{t}, 2 \mathrm{H}, J=5.2 \mathrm{~Hz}), 2.02-1.87(\mathrm{~m}, 4 \mathrm{H}), 1.62-1.52(\mathrm{~m}$, $4 \mathrm{H}), 1.42-1.36(\mathrm{~m}, 8 \mathrm{H}), 0.95-0.91(\mathrm{~m}, 6 \mathrm{H}) ;{ }^{13} \mathrm{C}$ NMR $(125 \mathrm{MHz}$, DMSO- $\left.d_{6}\right) \delta 166.9,157.5,153.4,148.7,137.2,136.5,128.2,121.2$, $120.5,120.1,114.4,111.9,109.6,103.8,72.5,70.0,69.9,69.8$, 69.7, 69.3, 69.2, 68.9, 67.2, 50.0,31.1, 29.8, 28.9, 26.1, 25.4, 25.2, 22.11, 22.08, 13.9, 13.9; MS (EI) $m / z 651\left(\mathrm{M}^{+}, 21\right), 582(28), 538$ (34), 365 (34), 281 (100), 252 (73), 224 (43).

12. (a) Matsuzawa, K.; Kosako, H.; Inagaki, N.; Shibata, H.; Mukai, H.; Ono, Y.; Amano, M.; Kaibuchi, K.; Matsuura, Y.; Azuma, I.; Inagaki, M. Biochem. Biophys. Res. Commun. 1997, 234, 621. (b) Okayama, N.; Fowler, M. R.; Jennings, S. R.; Specian, R.; Alexander, B.; Jackson, T. H.; Oshima, T.; Shannon, T.; Alexander, J. S. In Vitro Cell Dev. Biol. Anim. 2000, 36, 228. 